\title{
EDITORIAL
}

Eduardo Lopes Piris

Universidade Estadual de Santa Cruz, Ilhéus, Brasil

Paulo Roberto Gonçalves Segundo

Universidade de São Paulo, São Paulo, SP, Brasil

Maria Inês Batista Campos

Universidade de São Paulo, São Paulo, SP, Brasil

\section{A Argumentação nos Estudos do Texto e do Discurso}

Primeiramente...

Este número da Revista Linha D'Água é um exemplo do crescente interesse que a argumentação - tomada em suas múltiplas acepções - vem despertando nas ciências da linguagem no Brasil e em outras partes do mundo. Ao reunir doze artigos - onze inéditos e uma tradução - que se propuseram a refletir acerca da argumentação tanto em teorias textuais quanto em teorias discursivas, o resultado obtido foi a composição de um quadro de pluralidade teórica e de produtividade do trabalho interdisciplinar. As distintas perspectivas teóricas representadas neste encontro de tendências favorecem o enriquecimento do olhar do leitor para a argumentação, possibilitando a ampliação dos modos de conceber e de trabalhar com esse objeto de estudo.

Ruth Amossy - em um texto traduzido do original em espanhol - fundamenta-se no importantíssimo Tratado da Argumentação, de Perelman e Olbrechts-Tyteca, e nos trabalhos contemporâneos em Pragmática e em Narratologia para discutir a questão da interação argumentativa no discurso literário, especificamente, no relato de ficção. $\mathrm{O}$ interesse de seu artigo recai sobre a análise 
Linha D’Água (Online), São Paulo, v. 29, n. 2, p. 1-4, dez. 2016

da argumentação na ficção literária a partir das relações que o autor, narrador e personagens mantêm com o narratário. Já Christiani Margareth de Menezes e Silva trata da opinião em termos aristotélicos, encaminhando uma reflexão de caráter filosófico acerca do verdadeiro e do verossímil, apoiada no conceito de doxa, base para argumentos dialéticos e retóricos. Paulo Roberto Gonçalves-Segundo articula o modelo Toulmin de argumentação - uma das perspectivas responsáveis, juntamente com a de Perelman e Olbrechts-Tyteca, pelo renascer dos estudos retóricos e argumentativos no século XX - à perspectiva textual-interativa, para analisar uma entrevista de televisão durante o período de campanha eleitoral. Conforme o autor, o modelo Toulmin permite uma formalização esquemática da estrutura argumentativa que viabiliza uma análise crítica do processo, ao passo que a perspectiva textual-interativa fornece ferramentas explanatórias para a construção linguística do esquema argumentativo.

Eduardo Lopes Piris propõe uma reflexão acerca das bases teóricas que fundamentam o estudo da argumentação em perspectiva discursiva. Basicamente, mostra, de um lado, como Maingueneau e Amossy concebem, distintamente, a argumentação como um ramo da análise do discurso e, de outro lado, formula, com base em Pêcheux e Orlandi, uma concepção de argumentação como parte dos efeitos de sentido entre os sujeitos do discurso. Em seu trabalho, María Alejandra Vitale realiza diálogo similar, promovendo um encontro entre Perelman e Pêcheux, ao formular a noção de memória retórico-argumentativa e aplicá-la na análise de editoriais e de artigos da imprensa escrita brasileira que apoiou o golpe de 1964. Baseadas ainda na Análise de Discurso pecheutiana, Mónica Zoppi-Fontana \& Sheila Elias de Oliveira reúnem-se para tratar da relação entre discurso, enunciação e argumentação, analisando o funcionamento da argumentação em um fato de enunciação, a delocutividade, que implica retomadas do dizer, produzindo novas formas linguísticas a partir da relação de enunciação, tais como as interjeições delocutivas Tá serto e Só que não.

A articulação entre o arcabouço bakhtiniano e a argumentação pode ser vista no artigo de Maria Helena Cruz Pistori, que busca, a partir de dois gêneros distintos, investigar a persuasão nas relações dialógicas expressas por amplas e distintas esferas da atividade humana: a jornalística e a jurídica. Ariana de Carvalho \& 
Linha D’Água (Online), São Paulo, v. 29, n. 2, p. 1-4, dez. 2016

Mônica Santos de Souza Melo mergulham no domínio discursivo jurídico, articulando teorias argumentativas ao arcabouço semiolinguístico, de forma a examinar como os recursos das dimensões do logos e do pathos foram empregados pelo advogado para persuadir a juíza de que um pedido de indenização por danos morais é válido. Já Adriano Dantas de Oliveira, por sua vez, explora a esfera artística, focando as especificidades retóricas do texto cancional, a partir da obra de Chico Buarque, por meio de um diálogo entre argumentação e Semiótica. Para isso, propõe articular a melos - representativa de todos os aspectos musicais da canção - à tríade retórica clássica: ethos, pathos e logos, de modo a mostrar como aquela pode funcionar persusivamente.

Diversos artigos enfocam a relação entre argumentação e ensino, mostrando a importância que aquele domínio tem ocupado no âmbito dos estudos de Língua Portuguesa na escola, seja no Ensino Fundamental, seja no Médio. Isabel Cristina Michelan de Azevedo articula a Nova Retórica de Perelman \& Olbrechts-Tyteca à base teórica foucaultiana para refletir sobre as possibilidades de análise de produções discentes e de organização do ensino da argumentação na educação básica. A autora toma como base o ENEM e evidencia a necessidade de diversificar os processos de ensino e aprendizagem quando se quer ampliar as possibilidades de o sujeito assumir posicionamentos relativamente a outras posições. Maria Leidiana Alves \& Gilton Sampaio de Souza investigam um gênero típico do ensino superior na área de Letras: o relatório de estágio supervisionado. Os autores destacam a textualização de uma diversidade de pontos de vista - ancorados em argumentos de autoridade, superação, direção, modelo/antimodelo e da pessoa e seus atos, muitas vezes, antagônicos no que tange às teses sobre Ensino de Língua Portuguesa no Ensino Superior e na Educação Básica -, a destacar: a ausência de associação entre a prática desenvolvida pelo estagiário e a prática desenvolvida pelo professor da educação básica; a necessidade de articular teoria e prática no ensino de português; e a importância do estágio para o desenvolvimento de metodologias inovadoras para ensino. Por fim, Lauro Gomes parte da Teoria dos Blocos Semânticos, ligada a uma perspectiva de Argumentação na Língua, para apresentar uma proposta teoricamente ancorada de avaliação de leitura e de produção de textos 
Linha D’Água (Online), São Paulo, v. 29, n. 2, p. 1-4, dez. 2016

dissertativo-argumentativos, com o objetivo de qualificar a prática de docentes de educação básica no que concerne ao julgamento do desempenho discente.

Assim, esperamos que este número da Linha D'Água possa despertar o interesse e suscitar ainda mais a discussão sobre os problemas da argumentação colocados pelos autores presentes nesta edição.

Dezembro 2016 